\title{
SOSIALISASI SURVEILANS DALAM MENGHADAPI COVID-19 GELOMBANG KE-2
}

\author{
Ira Marti Ayu ${ }^{1}$, Rini Handayani ${ }^{1}$, Namira W. Sangadji ${ }^{1}$ \\ ${ }^{1}$ Program Studi Kesehatan Masyarakat Universitas Esa Unggul \\ Jalan Arjuna Utara no. 9, Kebon Jeruk, Jakarta Barat, 11510 \\ ira.marti@esaunggul.ac.id
}

\begin{abstract}
The pandemic of COVID-19 was also occurred in Indonesia where the highest cumulative case per 16 August 2020 was DKI Jakarta, one of the provinces in Indonesia. Because of large-scale social restriction (LSSR), many schools and colleges were closed. This aims to avoid the transmission of more cases. Even though the LSSR had been implemented but the cases remain increasing, so it needs to be socialized about surveillance for students and public health practitioners. This socialization was conducted online through Google meet. This socialization was carried out by presenting a topic about the introduction and advantages of surveillance using powerpoint media for \pm 20 minutes. After that, it was continued with the topic about surveillance in Indonesia to anticipate the $2^{\text {nd }}$ wave of COVID19 and the question and answer section. The results of the socialization showed that $76.9 \%$ of participants knew about the difference between survey and surveillance, 59\% knew the sequence of surveillance activity, $89.7 \%$ knew what types of surveillance were not carried out in Indonesia, and $60.3 \%$ knew about the surveillance stages after data analysis. It needs to socialize about surveillance to anticipate 2nd wave of COVID-19 cases continuously so that students and public health practitioners keep updating about the situation of the COVID-19 pandemic.
\end{abstract}

Kata kunci : socialization, surveillance, COVID-9

\begin{abstract}
Abstrak
Pandemi COVID-19 sudah melanda Indonesia dimana kasus kumulatif tertinggi per 16 Agustus 2020 yaitu DKI Jakarta sebagai salah satu provinsi di Indonesia. Karena PSBB maka banyak sekolah dan kampus ditutup ditutup. Hal ini dilakukan untuk menghindari penularan kasus lebih banyak lagi. Walaupun PSBB sudah dilakukan, kasus masih terus mengalami peningkatan. Oleh karena itu sosialisasi surveilans perlu dilakukan, Sosialisasi ini ditujukan kepada mahasiswa dan praktisi kesehatan masyarakat. yang dilakukan secara daring melalui aplikasi Google meeting. Kegiatan yang dilakukan dalam sosialisasi yaitu presentasi materi pengenalanan surveilans dan manfaatnya menggunakan media powerpoint \pm 20 menit, kemudian dilanjutkan dengan penyampaian materi pelaksaanaan surveilans di Indonesia untuk antisipasi COVID-19 Gelombang ke-2 dan sesi selanjutnya yaitu dengan tanya jawab. Hasil sosialisasi menunjukkan bahwa $76,9 \%$ tahu tentang perbedaan survei dan surveilans, 59\% tahu urutan kegiatan surveilans, $89.7 \%$ tahu jenis surveilans yang tidak dilaksanakan di Indonesia, dan $60.3 \%$ tahu tahapan surveilans setelah analisis data. Kegiatan sosialisasi tentang surveilans untuk mengantisipasi terjadinya lonjakan kasus COVID-19 gelombang kedua penting dilakukan secara berkesinambungan sehingga mahasis wa dan praktisi dapat mengetahui perkembangan pandemi COVID-19.
\end{abstract}

Kata kunci : sosialisasi, surveilans, COVID-9

\section{Pendahuluan}

Coronavirus disease 2019 (COVID-19) termasuk dalam penyakit menular yang baru muncul (new emerging disease). World Health Organization (WHO) menyatakan bahwa penyebab penyakit ini merupakan corona virus jenis baru yang belum pernah diidentifikasi sebelumnya pada manusia yang kemudian disebut dengan Severe Acute Respiratory Syndrome Coronavirus 2 (SARS-CoV-2). Pada 31 Desember 2019, WHO mengkonfirmasi kasus pneumonia yang penyebabnya tidak diketahui di Kota Wuhan, China. Kemudian pada 11 Maret 2020 terjadi peningkatan yang cepat untuk jumlah kasus di luar China dan kemudian sampai per 17 Agustus 2020 terdapat 21.516.760 terkonfirmasi kasus COVID-19 dengan 766.663 kematian di seluruh dunia yang berdampak pada 176 negara (WHO, 2020a).

Kasus COVID-19 yang terus meningkat di banyak negara membuat Organisasi Kesehatan Dunia (World Health Organization) menyatakan bahwa COVID-19 merupakan pandemi. Salah satu negara yang juga terdampak COVID-19 yaitu Indonesia dimana kasus pertama dilaporkan pada tanggal 2 Maret 2020. Sampai saat ini jumlah kasus terus meningkat dan menyebar di seluruh Provinsi di 
Indonesia. Per 17 Agustus 2020 terdapat 1.068. 945 kasus positif dengan 6.207 kasus meninggal dan $483 \mathrm{kab} /$ kota terdampak (Kemenkes RI, 2020b); (Kemenkes RI, 2020a).

Berdasarkan kondisi tersebut maka pemerintah mengeluarkan kebijakan pada 31 Maret 2020 yaitu melakukan Pembatasan Sosial Berskala Besar (PSBB). Kebijakan ini bertujuan untuk menekan penyebaran COVID-19. Pembatasan tersebut paling sedikit dilakukan melalui libur sekolah dan tempat kerja, pembatasan kegiatan keagamaan, dan/ atau pembatasan kegiatan di tempat umum atau fasilitas Umum, dan pembatasan perjalanan internasional (Pemerintah Republik Indonesia, 2020); (Kemenkes RI, 2020b). Beberapa daerah di Indonesia sudah melakukan pencabutan PSBB atau sudah memasuki masa PSBB transisi pada Juni dimana kasus COVID-19 masih terus bertambah terutama di DKI Jakarta.

Penanggulangan Pandemi COVID-19 sampai saat ini masih berlangsung sehingg diperlukan suatu tindakan untuk menemukan kasus tambahan dan mencegah penyebaran kasus. Adapun kegiatan tersebut dikenal dengan surveilans (WHO, 2020b). Tujuan untuk dilakukan surveilans yaitu dapat memantau tren penularan COVID-19, melakukan deteksi cepat pada wilayah tanpa transmisi virus dan monitoring kasus pada wilayah dengan transmisi virus termasuk pada populasi rentan, memberikan informasi epidemiologi untuk melakukan penilaian risiko, memberikan informasi epidemiologi sebagai acuan kesiapsiagaan dan respon penanggulangan serta memberikan evaluasi terhadap dampak pandemi pada sistem pelayanan kesehatan dan sosial (Kemenkes RI, 2020b). Peningkatan kasus COVID-19 masih terus terjadi di Indonesia dan DKI Jakarta merupakan kasus terbanyak sampai saat ini maka diperlukan sosialisasi tentang surveilans untuk mengantisipasi penambahan kasus yang lebih banyak lagi setelah masa PSBB mulai dicabut.

\section{Metode Pelaksanaan}

Kegiatan sosialisasi ini akan dilaksanakan secara daring melalui aplikasi Google meet. Kegiatan ini akan dilakukan pada bulan Juni 2020. Adapun sasaran dari kegiatan ini yaitu mahasiswa dan praktisi kesehatan masyarakat. Kegiatan sosialisasi akan dilakukan dengan empat (4) tahapan, yaitu sosialisasi, diskusi dan tanya jawab, post-test dan evaluasi. Berikut merupakan penjabarannya:

1. Sosialisasi

Sosialisasi dilakukan dengan penyampaian materi sosialisasi. Adapun materi yang disampaikan yaitu tentang pengantar surveilans, pelaksanaan surveilans di Indonesia untuk antisipasi COVID-19 gelombang kedua, kemudian diseminasi hasil surveilans yang dilakukan di lingkungan civitas akademik Universitas Esa Unggul. Sosialisasi ini dilakukan dengan menggunakan media powerpoint.

2. Diskusi dan tanya jawab

Diskusi dan tanya jawab ini dilakukan untuk merespon pemahaman mahasiswa dan praktisi kesehatan masyarakat mengenai materi yang disampaikan. Sesi Tanya jawab akan menggunakan aplikasi Sli.do. Peserta akan menuliskan pertanyaan dalam aplikasi tersebut. Sesi diskusi dan tanya jawab akan dipimpin oleh moderator. Moderator akan membacakan pertanyaan yang sudah dituliskan dalam Sli.do

3. Post-test

Setelah sosialisasi surveilans dilakukan kemudian pengukuran pengetahuan dilakukan dengan menanyakan 5 pertanyaan. Post-test dilakukan dengan aplikasi Google Form

4. Evaluasi

Evaluasi kegiatan dilakukan dengan meminta feedback terhadap kegiatan pengabdian kepada masyarakat. Evaluasi ini juga dilakukan dengan pengisian aplikasi Google Form bersamaan dengan absensi kegiatan sosialisasi.

\section{Hasil}

Pengabdian kepada masyarakat ini dilakukan pada tanggal 10 Juni 2020, yang dimulai pada pukul 10.00 WIB sampai dengan jam 12.00 WIB dengan total peserta 200 mahasiswa dan praktisi kesehatan masyarakat. Setelah peserta kegiatan yaitu mahasiswa dan praktisi kesehatan masyarakat bergabung dalam Google meet kemudian panitia membuka acara yang dimulai dengan acara pembukaan dan kata sambutan. Kemudian dilakukan pelaksanaan sosialisasi surveilans yang isinya berkaitan dengan pengertian surveilans, perbedaan survei 
dan surveilans, urutan kegiatan surveilans, jenis melakukan tanya jawab. surveilans di Indonesia, tahapan surveilans dan

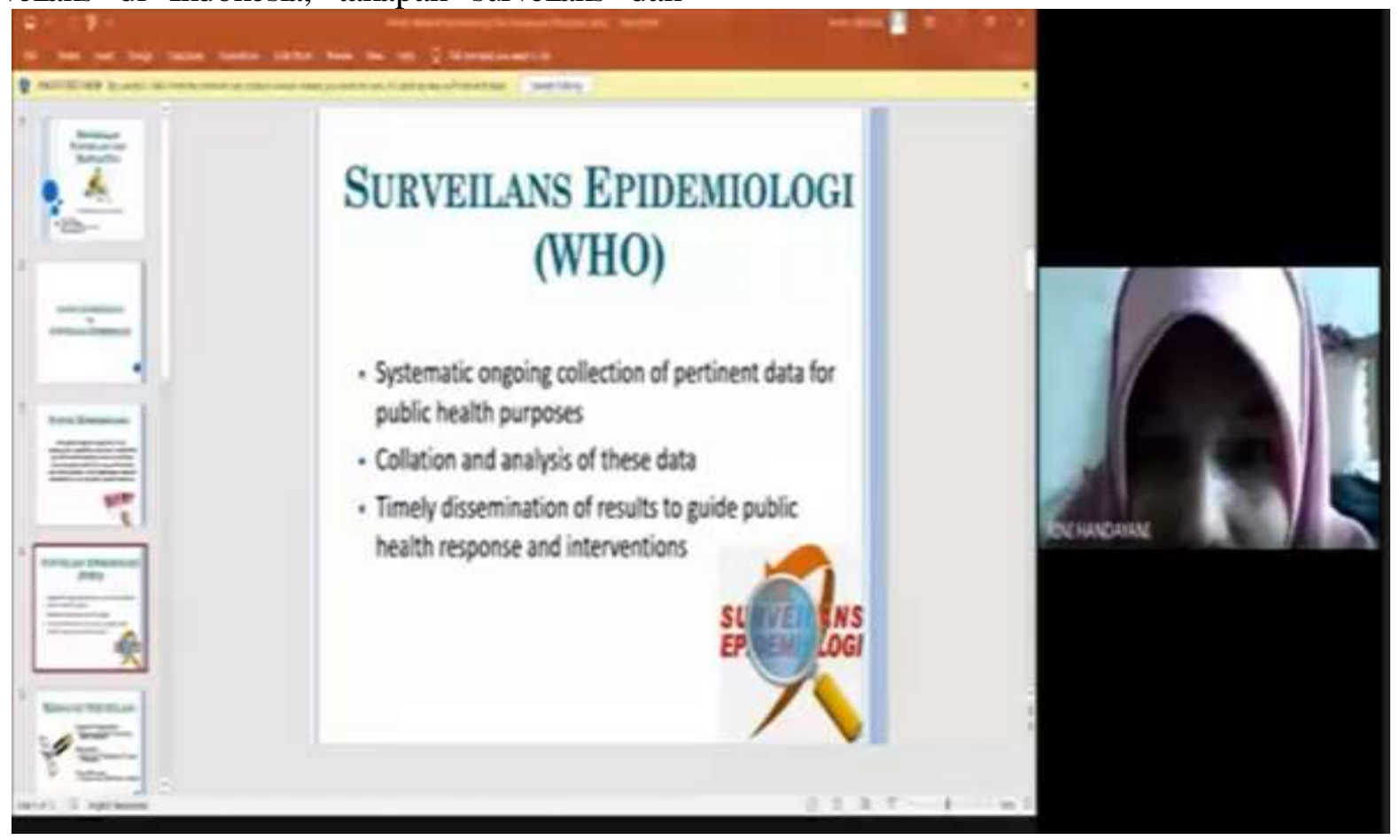

Gambar 1. Penyampaian materi sosialisasi melalui aplikasi Google meet

Kegiatan tanya jawab dibuka dalam 3 sesi. Pada setiap sesi dibuka 3 pertanyaan untuk 3 penanya. Total pertanyaan yg terjawab adalah 9 pertanyaan. Meskipun demikian masih terdapat 2 pertanyaan lagi yang belum sempat dijawab oleh responden karena keterbatasan waktu. Berikut merupakan beberapa pertanyaan yang ditanyakan melalui aplikasi Sli.do:

a. Penyelidikan Epidemiologi terhadap suatu kasus biasanya dilakukan ketika adanya kesakitan, apakah PE bisa dilakukan secara berkala tanpa adanya kesakitan? Apa tindak lanjut yang dilakukan oleh tenaga Surveilans puskesmas dalam meminimalisir terjadi penyebaran COVID-19 di daerah terkait dengan pelonggaran PSBB?

b. Bagaimana prediksi secara nasional untuk COVID-19 ini pada 2021? apakah tahun depan sudah bisa dikendalikan atau masih menjadi wabah? Apakah COVID-19 ini nantinya akan ditambahkan dalam program kesehatan (seperti Program TBC, HIV, Hepatitis, dll) jika COVID-19 tidak berhasil ditanggulangi atau dihilangkan?

c. Dalam kegiatan surveilans sampai saat ini apakah ada kendala dalam penggunaan atau pengolahan data khusus di tingkat kab/ kota-provinsi?

d. Berapa lama waktu efektif yang dibutuhkan untuk surveilans suatu kasus agar bisa memberikan hasil analisis yang optimal? Apakah kasus surveilans ini bisa diterapkan di bidnag lain selain bidang kesehatan?. 


\section{berapa lama waktu efektif yang dibutuhkan untuk surveilens suatu kasus agar bisa menghasilkan hasil analisa yang optimal?}

\section{V 10. Jun 2020, 12:31 PM \\ apakah kasus surveilens ini bisa kita terapkan dibidang lain selain bidang kesehatan?}

\section{Gambar 2. Diskusi dan Tanya Jawab melalui aplikasi Sli.do}

Setelah penyampaian materi dan sesi tanya jawab maka dilakukan pengukuran pengetahuan. Berikut merupakan hasil post-test berkaitan dengan surveilans

Tabel 1. Proporsi pengetahuan tentang surveilans setelah penyampaian materi sosialisasi dilakukan

\begin{tabular}{|c|c|c|}
\hline No & Pertanyaan & $(\%)$ \\
\hline 1. & 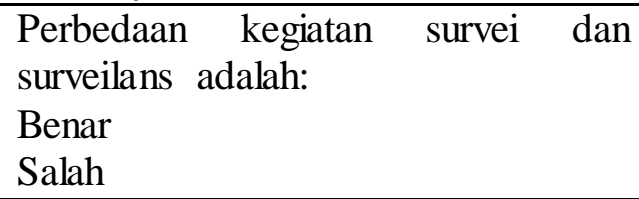 & $\begin{array}{l}76,9 \\
23.1\end{array}$ \\
\hline 2. & $\begin{array}{lll}\text { Urutan kegiatan } & \text { surveilans } & \text { yang } \\
\text { benar adalah: } & & \\
\text { Benar } & & \\
\text { Salah } & & \\
\end{array}$ & $\begin{array}{l}59,0 \\
42.0\end{array}$ \\
\hline 3. & $\begin{array}{l}\text { Jenis surveilans yang tidak } \\
\text { dilaksanakan di Indonesia adalah: } \\
\text { Benar } \\
\text { Salah }\end{array}$ & $\begin{array}{l}89,7 \\
10.3\end{array}$ \\
\hline 4. & $\begin{array}{l}\text { Setelah menetapkan tujuan, tahap } \\
\text { selanjutnya dalam surveilans adalah: } \\
\text { Benar } \\
\text { Salah }\end{array}$ & $\begin{array}{l}43,6 \\
56.4\end{array}$ \\
\hline 5. & $\begin{array}{l}\text { Setelah dilakukan analisis data, } \\
\text { tahap selanjutnya dalam tahapan } \\
\text { surveilans adalah: } \\
\text { Benar } \\
\text { Salah }\end{array}$ & $\begin{array}{l}60,3 \\
39.7\end{array}$ \\
\hline
\end{tabular}

Berdasarkan tabel 1 terlihat bahwa sebagian besar peserta menjawab benar pada pertanyaan nomor $1(76,9 \%)$, nomor $2(59,0 \%)$, nomor $3(89,7 \%)$, dan nomor $5(60,3 \%)$. Pada pertanyaan nomor 4 , sebagian besar menjawab salah. Jawaban yang benar terkait pertanyaan tersebut adalah mengembangkan definisi kasus. Adapun dalam tahapan surveilans, setelah penetapan tujuan adalah definisi kasus. Namun dalam banyak kegiatan, definisi ditulis lebih dahulu dibandingkan tujuan. Mungkin ini yang menjadikan peserta ragu dalam menjawab sehingga kebanyakan peserta akan menjawab mengembangkan sistem pengumpulan data $(19,2 \%)$ dan mengembangkan instrumen pengumpulan data $(21,2 \%)$.

\section{Pembahasan}

Centrers for Disease Control and Prevention (CDC) mendefenisikan surveilans yaitu the ongoing systematic collection, analysis, and interpretation of health-related data essential to the planning, implementation, and evaluation of public health practice, closely integrated with the timely dissemination of these data to those who need to know. Sampai saat ini sudah banyak surveilans yang dikembangkan di dunia juga di Indonesia baik surveilans penyakit menular ataupun penyakit tidak menular (Lee et al, 2010); (Lombardo \& Buckeridge, 2012).

Surveilans merupakan suatu intervensi yang penting dilakukan dalam memprediksi pandemi termasuk didalamnya pandemi COVID-19 (Morse et al., 2012); (Ibrahim, 2020). Oleh karena itu sosialisasi perlu dilakukan agar mahasiswa dan praktrisi kesehatan masyarakat dapat mengetahui tentang surveilans dan pelaksaanan surveilans di Indonesia untuk mengatasi pandemi COVID-19. Kegiatan ini dilakukan secara daring mengingat 
pemerintah sudah menerapkan kebijakan pysical distancing. Hal ini dilakukan untuk menurunkan angka penularan COVID-19 (Islam et al., 2020); (MacIntyre, 2020).

Kegiatan webinar ini merupakan sosialisasi surveilans. Sosialisasi surveilans yang dilakukan merupakan bentuk dari penyuluhan kesehatan. Penyuluhan kesehatan banyak tujuan seperti untuk meningkatkan pengetahuan, kemauan, kesadaran, memperbaharui sikap dan persepsi agar dapat berperilaku lebih baik serta pada akhirnya berpengaruh pada perilaku atau tindakan seseorang dalam bidang kesehatan (Hulu et al., 2020); (World Health Organization., 2012); (Snelling, 2014). Banyak penelitian menunjukkan bahwa penyuluhan yang berupa pendidikan kesehatan berkaitan dengan peningkatan pengetahuan (Viero et al., 2015); (Wang et al., 2018). Selain itu, pengetahuan kesehatan juga berkaitan dengan perilaku kesehatan (Neamatollahi et al., 2011); (Grosso et al., 2013).

Kegiatan sosialisasi ini dilakukan dengan kelompok besar dimana metode yang digunakan yaitu ceramah dan presentasi. Adapun tujuan kegiatan ini yaitu untuk memberikan informasi berkaitan dengan surveilans dan penerapan surveilans dalam mencegah peningkatan kasus COVID-19 di Indonesia. Informasi yang diberikan harapannya dapat memberikan pengetahuan bagi peserta webinar. Syarifudin dan Yudhia F (2009) dalam Hulu et al., (2020) menyatakan bahwa ceramah dan presentasi merupakan metode penyuluhan yang dapat digunakan untuk merubah pengetahuan.

Pelaksanaan sosialisasi juga tidak terlepas dengan penggunaan media dalam penyampaian materi. Media yang digunakan dalam sosialisasi ini yaitu powerpoint. Media merupakan perantara yang digunakan dalam penyampaian pesan dan informasi (komunikasi) antara komunikator dengan komunikan (Gejir et al., 2017). Media promosi kesehatan dapat berupa media cetak, media elektronik dan media papan. Slide powerpoint termasuk dalam media elektronik dimana media ini dapat digunakan untuk menyampaikan pesan (Notoatmodjo, 2007). Asyar (2011) dalam (Gejir et al., 2017) menyebutkan juga bahwa media komunikasi ada empat (4) yaitu media visual, media audio, media audio visual dan multimedia. Presentasi dengan powerpoint termasuk dalam media multimedia. Hasil abdimas yang dipublikasi oleh (Ayu et al., 2020) menunjukkan bahwa terjadi peningkatan pengetahuan remaja setelah dilakukan penyuluhan berkaitan kesehatan reproduksi dengan menggunakan media powerpoint.

Kegiatan pengabdian masyarakat ini banyak mendapat dukungan dari pihak prodi kesehatan masyarakat, mahasiswa dan praktisi kesehatan masayarakat. Hal ini terlihat bahwa peserta yg hadir berasal dari mahasiswa Universitas Esa Unggul dan juga kampus lain seperti Universitas Muhammadiyah Surakarta, Poltekkes Kemenkes Yogyakarta, Universitas Jambi dll. Selain itu sosialisasi ini juga diikuti oleh praktisi kesehatan masyarakat yg berasal dari institusi Kantor Kesehatan Pelabuhan Bandung, Dinas Kesehatan Kota Tangerang, Puskesmas Sei Balai, Kab. Batubara, Prov. Sumatera Utara dll.

Adapun hasil evaluasi yang diberikan oleh peserta yaitu peserta menyatakan kegiatan sudah sangat baik untuk topiknya, kuota peserta ditambah, agar dibuat kegiatan webinar selanjutnya, lebih sering dilaksanakan guna mengembangkan dan menambah wawasan serta informasi terbaru, membuat topik yang lebih baik dan lebih menarik lagi terkait isu kasus Epidemiologi atau isu kesehatan masyarakat yang lainnya, dan ada yang menyarankan untuk topik-topik webinar selanjutnya.

\section{Kesimpulan}

Kegiatan pengabdian masyarakat berupa penyuluhan kesehatan dengan media powerpoint dapat digunakan meningkatkan pengetahuan peserta. Kegiatan yang dilakukan dapat menunjukkan bahwa sebagian besar peserta dapat menjawab pertanyaan post-test dengan benar. Kegiatan pengabdian masyarakat berjalan dengan lancar dan mendapat dukungan dari pihak universitas. Selain itu, peserta yang hadir cukup banyak dan mengikuti dari awal hingga akhir acara.

\section{Ucapan Terima kasih}

Kegiatan ini terlaksana atas kerjasama berbagai pihak tim pelaksana yaitu Tim dosen Epidemiologi, Prodi kesehatan Masyarakat Universitas Esa Unggul, dan juga Himpunan 
Mahasiswa Jurusan (HMJ) Prodi Kesehatan Masyarakat Universitas Esa Unggul, juga Kementrian Kesehatan

\section{Daftar Pustaka}

Ayu, I. M., Situngkir, D., Nitami, M., \& Nadiyah, N. (2020). Program peningkatan pengetahuan kesehatan reproduksi remaja di SMK "X" Tangerang Raya. Jurnal Kreativitas Pengabdian Masyarakat (PKM), 3(1), 87-95. Retrieved from http://ejurnalmalahayati.ac.id/index.php/ kreativitas/article/view/2412/pdf

Gejir, I. N., Agung, A. A. G., Ratih, I. A. D. K., Mustika, I. W., Suanda, I. W., Widiari, N. N., \& Wirata, I. N. (2017). Media Komunikasi dalam Penyuluhan Kesehatan (I. A. D. K. Ratih, Ed.). Retrieved from https://books.google.co.id/books?id=Ti5 LDwAAQBAJ\&printsec $=$ frontcover\&dq $=$ media + penyuluhan + kesehatan $\& h l=e n$ $\&$ sa $=$ X\&ved $=2$ ahUKEwjOlbDjZPuAhVJeX0KHfZMAIEQ6AEwAH $o E C A M Q A g \# v=$ onepage $\& q \& \mathrm{f}=$ false

Grosso, G., Mistretta, A., Turconi, G., Cena, H., Roggi, C., \& Galvano, F. (2013). Nutrition knowledge and other determinants of food intake and lifestyle habits in children and young adolescents living in a rural area of Sicily, South Italy. Public Health Nutrition, 16(10), 1827-1836.

https://doi.org/10.1017/S1368980012003 965

Hulu, V. T., Pane, H. W., Zuhriyatun, T. F., Munthe, S. A., Salman, S. H., Sulfianti, ... Mustar. (2020). Promosi Kesehatan Masyarakat (J. Simarmarta, Ed.). Retrieved from https://books.google.co.id/books?id=vw wLEAAAQBAJ \&pg $=$ PA55\&dq=media + penyuluhan + kesehatan $\& h l=e n \& s a=X \&$ ved=2ahUKEwjOlb-

DjZPuAhVJeX0KHfZMAIEQ6AEwAX oECAEQAg\# $\mathrm{v}=$ onepage $\& \mathrm{q}=$ media penyuluhan kesehatan $\& \mathrm{f}=$ false

Ibrahim, N. K. (2020, November 1). Epidemiologic surveillance for controlling Covid-19 pandemic: types, challenges and implications. Journal of
Infection and Public Health, Vol. 13, pp. 1630-1638.

https://doi.org/10.1016/j.jiph.2020.07.01 9

Islam, N., Sharp, S., Chowell, G., Shabnam, S., Bmj, I. K.-, \& 2020, U. (2020). Physical distancing interventions and incidence of coronavirus disease 2019: natural experiment in 149 countries. British Medical Journal, 370, 1-9. Retrieved from

https://www.bmj.com/content/370/bmj. m2743.long

Kemenkes RI. (2020a). COVID-19 Update hingga 17 Agustus 2020 Pukul 16.00 WIB. Retrieved from https://covid19.kemkes.go.id/

Kemenkes RI. (2020b). Pedoman Pencegahan dan pengendalian Corona Virus Disease (COVID-19) Revisi ke-5. Retrieved from https://covid19.go.id/p/protokol/pedoma n-pencegahan-dan-pengendaliancoronavirus-disease-covid-19-revisi-ke-5

Lee, L. M., Teutsch, S. M., Thacker, S. B., \& St Louis, M. E. (2010). Principles and Practice of Public Health Surveillance (Third). Retrieved from https://books.google.co.id/books?id=FF7 $8 \mathrm{GCiUbwUC} \&$ printsec $=$ frontcover $\& \mathrm{dq}=$ surveillance+of+public + health \&hl=en\&s $\mathrm{a}=$ X\&ved=2ahUKEwiikZzdlJPuAhUX9 nMBHQpiBp0Q6AEwA3oECAMQAg\# $\mathrm{v}=$ onepage $\& \mathrm{q}=$ surveillance of public health $\& \mathrm{f}=$ false

Lombardo, J. S., \& Buckeridge, D. L. (2012). Disease Surveillance: A Public Health Informatics Approach. Retrieved from https://books.google.co.id/books?id=$\mathrm{xI} 2 \mathrm{~K} 139$ ZzoC\&printsec $=$ frontcover\&dq $=$ surveillance + of + public + health $\& h=e n$ $\&$ sa $=X \& v e d=2$ ahUKEwiikZzdlJPuAhU X9nMBHQpiBp0Q6AEwAnoECAYQA $\mathrm{g \# v}=$ onepage $\& \mathrm{q}=$ surveillance of public health $\& \mathrm{f}=$ false

MacIntyre, C. R. (2020, October 1). Case isolation, contact tracing, and physical distancing are pillars of COVID-19 pandemic control, not optional choices. The Lancet Infectious Diseases, Vol. 20, pp. 1105-1106. https://doi.org/10.1016/S14733099(20)30512-0 
Morse, S. S., Mazet, J. A. K., Woolhouse, M., Parrish, C. R., Carroll, D., Karesh, W. B., ... Daszak, P. (2012, December 1). Prediction and prevention of the next pandemic zoonosis. The Lancet, Vol. 380 , pp. $1956-1965$

https://doi.org/10.1016/S0140-

6736(12)61684-5

Neamatollahi, H., Ebrahimi, M., Talebi, M., Ardabili, M. H., \& Kondori, K. (2011). Major differences in oral health knowledge and behavior in a group of Iranian pre-university students: a crosssectional study. Journal of Oral Science, 53(2), 177-184. Retrieved from https://www.jstage.jst.go.jp/article/josnu sd/53/2/53_2_177/_article/-char/ja/

Notoatmodjo, S. (2007). Promosi Kesehatan dan Ilmu perilaku. Jakarta: PT Rineka Cipta.

Pemerintah Republik Indonesia. Peraturan Pemerintah Republik Indonesia No 21 Tahun 2020 tentang Pembatasan Sosial Berskala Besar Dalam Rangka Percepatan Penanganan Corona Virus Disease 2019 (COVID-19). , Pub. L. No. Peraturan Pemerintah Republik Indonesia No 21 Tahun 2020 (2020).

Snelling, A. (2014). Introduction to Health Promotion. Retrieved from https://books.google.co.id/books?id=ZH JMBAAAQBAJ\&printsec $=$ frontcover\& $\mathrm{dq}=$ media + penyuluhan+kesehatan $\& \mathrm{hl}=\mathrm{e}$ $\mathrm{n} \& \mathrm{sa}=\mathrm{X} \& \mathrm{ved}=2 \mathrm{ahUKEwjOlb}-$

DjZPuAhVJeX0KHfZMAIEQ6AEwBno ECAkQAg\#v=onepage \&q\& $\mathrm{f}=$ false

Viero, V. dos S. F., Farias, J. M. de, Ferraz, F., Simões, P. W., Martins, J. A., \& Ceretta, L. B. (2015). Health education with adolescents: analysis of knowledge acquisition on health topics. Escola Anna Nery - Revista de Enfermagem, 19(3), 484-490.

https://doi.org/10.5935/1414-

8145.20150064

Wang, M., Han, X., Fang, H., Xu, C., Lin, X., Xia, S., ... Tao, H. (2018). Impact of Health Education on Knowledge and Behaviors toward Infectious Diseases among Students in Gansu Province, China. BioMed Research International, 2018, https://doi.org/10.1155/2018/6397340

WHO. (2020a). Coronavirus disease (COVID19) pandemic. Retrieved from https://www.euro.who.int/en/healthtopics/health-emergencies/coronaviruscovid-19/novel-corona virus-2019-ncov

WHO. (2020b). Emerging respiratory viruses, including COVID-19: methods for detection, prevention, response and control. Retrieved from https://openwho.org/courses/introduction -to-ncov

World Health Organization. (2012). Health education: theoretical concepts, effective strategies and core competencies $A$ foundation document to guide capacity development of health educators. Retrieved from https://applications.emro.who.int/dsaf/E MRPUB_2012_EN_1362.pdf 